\title{
Antioxidant and Anti-Inflammatory Effect of Probiotic Lactobacillus plantarum KU15149 Derived from Korean Homemade Diced-Radish Kimchi
}

\author{
Kyoung Jun Han, Ji-Eun Lee, Na-Kyoung Lee, and Hyun-Dong Paik* \\ Department of Food Science and Biotechnology of Animal Resources, Konkuk University, Seoul 05029, Republic of \\ Korea \\ Lactobacillus plantarum KU15149 was demonstrated to have probiotic behavior and functions, \\ including antioxidant and anti-inflammatory activity. L. plantarum KU15149 obtained from \\ homemade diced-radish kimchi has a high survival rate under artificial gastric acid (pH 2.5, 0.3\% \\ pepsin) and bile salt ( $0.3 \%$ oxgall) conditions. However, L. plantarum KU15149 did not produce \\ $\beta$-glucuronidase, which is known to be a carcinogenic enzyme with resistance to several antibiotics, \\ such as gentamycin, kanamycin, streptomycin, tetracycline, and ciprofloxacin. L. plantarum \\ KU15149 strongly adhered to HT-29 cells and had high antioxidant activity in terms of 2,2-diphenyl- \\ 1-picrylhydrazyl (DPPH) free radical-scavenging and $\beta$-carotene bleaching assays. L. plantarum \\ KU15149 also exhibited a pronounced inhibition of nitric oxide (NO) production, along with \\ expression of nitric oxide synthase (iNOS) and cyclooxygenase -2 (COX-2) as well as pro- \\ inflammatory cytokines, such as TNF- $a, I L-1 \beta$, and IL-6, when RAW 264.7 cells were stimulated with \\ LPS. Therefore, L. plantarum KU15149 exhibited pharmaceutical functionality as a potential \\ probiotic.
}

Keywords: Probiotics, kimchi, Lactobacillus plantarum, antioxidant, anti-inflammatory

Received: February 26, 2020 Accepted: March 20, 2020

First published online: March 24, 2020

*Corresponding author Phone: +82-2-2049-6011 Fax: +82-2-455-3082 E-mail: hdpaik@konkuk.ac.kr

pISSN 1017-7825 elSSN 1738-8872

Copyright(C) 2020 by The Korean Society for Microbiology and Biotechnology

\section{Introduction}

Oxidative stress is caused by a pro-oxidant and antioxidant imbalance that leads to the generation of toxic reactive oxygen species (ROS), such as hydrogen peroxide, organic hydroperoxides, superoxide, hydroxyl radicals, and nitric oxide. Persistent oxidative damage of tissue and cellular components can cause several diseases and accelerate the aging process in humans [1]

Inflammatory reactions and ROS perform indispensable physiological functions in immune defense and cell signaling [2]. However, undue or continued ROS production and inflammation may result in a number of health problems, such as type 2 diabetes, cardiovascular disease, osteoporosis, insulin resistance, inflammatory bowel disease, arthritis, and asthma [3]. Therefore, ROS levels and inflammatory responses are important for reducing the risk of related chronic diseases.

The inflammatory response in the body is a defense against risk stimuli, including microbial infections, endotoxins, and tissue damage, and it is necessary to restore the normal structure and function of tissues. Normal inflammatory responses have a regulatory process during which the production of pro-inflammatory mediators decreases over time, while anti-inflammatory mediators rise in number, thereby limiting the inflammatory response itself [4]. Macrophages, one of the cell types involved in the body's inflammatory response, play an important role in this inflammatory response. Macrophages are activated by pro-inflammatory cytokines, such as tumor necrosis factor (TNF)- $\alpha$, interleukin (IL)-1 $\beta, I L-6$, and lipopolysaccharide (LPS), and exposure to LPS stimulation, which is a bacterial cell membrane component. In addition, macrophages produce various inflammatory mediators, such as nitric oxide (NO) through expression of inducible nitric oxide synthase (iNOS) and cyclooxygenase $-2(\mathrm{COX}-2)[5]$.

Probiotics are defined as live microorganisms that when administered in appropriate amounts, confer a beneficial effect upon the host [6] and contribute to the regulation of immune responses [7]. Lactic acid bacteria (LAB) have been used as probiotics and can survive under strong acid and bile salt conditions while adhering to the cells of the intestinal tract [8]. LAB strains are also generally known to be non-pathogenic and sensitive to antibiotics [9]. In addition, several studies have reported that probiotics have antimicrobial, antioxidant, anticancer, antiallergy, and immune-enhancing activities [10,11]. Probiotics have also been reported to have several positive and beneficial effects on human health [12]. 
Kimchi is a Korean traditional fermented vegetable product that is gaining popularity as a functional food as it contains various LAB, such as Lactobacillus plantarum and Leuconostoc mesenteroides [13]. In particular, LAB strains isolated from kimchi can survive in the intestines due to their strong resistance to acid and bile salt conditions [14]. Kimchi LAB are probiotic strains that exert various beneficial effects, such as antioxidant, antimicrobial, antimutagenic, anticancer, immune-regulation, anti-inflammatory, antiallergic, anti-obesity, cholesterol-lowering, and lipid-lowering activities [15].

L. plantarum is the most important and prominent microorganism involved in the middle and latter steps of kimchi fermentation [16]. L. plantarum is a generally recognized as safe (GRAS) microorganism and has been used as a probiotic strain and fermentation starter in various foods, including meat, dairy products, plant-based products, and coffee [17]. Furthermore, various studies have reported that $L$. plantarum has immune stimulation, inflammatory reduction, and antioxidant activities [18].

Therefore, the aim of the present study was to determine the probiotic properties, safety, and functional effects of LAB strains isolated from homemade diced-radish kimchi. Further, the antioxidant and anti-inflammatory activities of the isolated strains were investigated.

\section{Material and Methods \\ Chemicals and Reagents}

MRS and oxgall were purchased from Becton Dickinson Biosciences (USA). Pepsin, ascorbic acid, $\beta$-carotene, linoleic acid, chloroform, Tween 80, Triton X-100, 2,2-diphenyl-1-picrylhydrazyl (DPPH), lipopolysaccharide (LPS), 3-(4,5-dimethylthiazol-2-yl)-2,5-diphenyltetrazolium bromide (MTT), dimethyl sulfoxide (DMSO), and Griess reagent were purchased from Sigma Chemical Co., Ltd. (USA). Dulbecco's Modified Eagle's Medium (DMEM), RPMI1640, water, antibiotics, fetal bovine serum (FBS), phosphate-buffered saline (PBS), and $1 \%$ streptomycin/penicillin solution were purchased from HyClone Laboratories, Inc. (USA). The API ZYM kit was purchased from bioMérieux (France). Specific primers used for performing the real-time polymerase chain reaction (RT-PCR) were purchased from Bionics (Korea).

\section{Bacterial Strains and Sample Preparations}

Lactobacillus plantarum KU15149 was isolated from homemade diced-radish kimchi. Kimchi samples (1 g) were diluted and inoculated on MRS agar at $37^{\circ} \mathrm{C}$ for $24 \mathrm{~h}$. The selected strain was inoculated and incubated in MRS broth at $37^{\circ} \mathrm{C}$ for $24 \mathrm{~h}$ and identified as L. plantarum by $16 \mathrm{~S}$ rRNA gene sequencing. The commercial probiotic strain, L. rhamnosus GG (LGG), was obtained from the Korean Collection for Type Cultures (Korea) and used as a reference probiotic strain. To harvest the $\mathrm{LAB}$ cells, bacterial cell cultures were centrifuged at $12,000 \times g$ for $10 \mathrm{~min}$ and washed three times with PBS. The LAB cells were suspended in PBS.

\section{Cell Cultures}

HT-29 (human colon adenocarcinoma) and RAW 264.7 (murine macrophage) cell lines were obtained from the Korean Cell Line Bank (Korea) and respectively cultured in RPMI and DMEM supplemented with 10\% FBS and $1 \%$ streptomycin/penicillin solution at $37^{\circ} \mathrm{C}$ in a humidified atmosphere containing $5 \% \mathrm{CO}_{2}$.

\section{Tolerance to Artificial Gastric Conditions of LAB Strains}

The tolerance of LAB strains to artificial gastric conditions was evaluated as described by Lee et al. [19]. The LAB strains were incubated in an overnight culture and resuspended in the MRS medium ( $\mathrm{pH} 2.5)$ containing $0.3 \%(\mathrm{w} / \mathrm{v})$ pepsin and oxgall, and then incubated at $37^{\circ} \mathrm{C}$ for $3 \mathrm{~h}$ and $24 \mathrm{~h}$. The number of surviving bacteria was determined by counting viable cells on the MRS plates.

\section{Enzyme Production of LAB Strains}

Enzyme production was assessed using the API ZYM kit. The LAB strains were centrifuged at $12,000 \times g$ for $10 \mathrm{~min}$, and the cell pellet was resuspended in PBS at $10^{5} \mathrm{CFU} / \mathrm{ml}$ and added to the cultures. After inoculation, the mixtures were incubated at $37^{\circ} \mathrm{C}$ for $4 \mathrm{~h}$ and reagents zym $\mathrm{A}$ and zym $\mathrm{B}$ were each added. The level of enzyme activity was determined as 0 (no activity) to $5(\geq 40 \mathrm{nM}$ ) based on the color change.

\section{Adhesion of LAB Strains to HT-29 Cells}

The adhesion ability of LAB strains to HT-29 cells was described as the percentage of viable bacteria remaining as compared to the initial bacterial counts added. Adherence to HT-29 cells of LAB strains was assessed by the methodology of Son et al. [11]. For the adhesion assays, $1 \times 10^{5} \mathrm{cells} / \mathrm{ml}$ of HT-29 cells were seeded onto a 24-well cell culture plate and incubated at $37^{\circ} \mathrm{C}$ for $24 \mathrm{~h}$. The $\mathrm{LAB}$ strains were centrifuged at $12,000 \times g$ for $10 \mathrm{~min}$ and washed twice with PBS before being inoculated on the wells at approximately $10^{7} \mathrm{CFU} / \mathrm{ml}$ and incubated for $2 \mathrm{~h}$ at $37^{\circ} \mathrm{C}$. Non-adhesive bacteria were removed by washing three times with PBS. Next, $1 \mathrm{ml}$ of $1 \%(\mathrm{v} / \mathrm{v})$ Triton X-100 was added into each well and incubated for $10 \mathrm{~min}$ at $37^{\circ} \mathrm{C}$. Following incubation, the cells were separated from the wells. The number of adherent bacterial cells was indicated by counting viable cells on the MRS plates.

\section{Antibiotic Sensitivity of LAB Strains}

Sensitivity of the LAB strains was measured according to the guidelines of the Clinical and Laboratory Standards Institute (CLSI) [20]. The disc diffusion method was applied to determine sensitivity to clinical antibiotics, such as ciprofloxacin $(5 \mathrm{mg})$, gentamicin $(10 \mathrm{mg})$, ampicillin $(10 \mathrm{mg})$, streptomycin $(10 \mathrm{mg})$, tetracycline $(30 \mathrm{mg})$, kanamycin $(30 \mathrm{mg})$, doxycycline $(30 \mathrm{mg})$, and chloramphenicol $(30 \mathrm{mg})$. Each LAB strain, at a concentration of 
$10^{7} \mathrm{CFU} / \mathrm{ml}$, was spread on MRS agar, and paper discs containing the antibiotics were placed on plates after a few minutes. Subsequent to incubation for $24 \mathrm{~h}$ at $37^{\circ} \mathrm{C}$, the diameters of the inhibition zones were measured.

\section{Preparation of Bacterial Cells}

The LAB strains were grown in MRS broth overnight, centrifuged at 12,000 $\times g$ for $10 \mathrm{~min}$, and washed twice with PBS. The washed bacterial cells were resuspended in PBS to a final concentration of $10^{8} \mathrm{CFU} / \mathrm{ml}$.

\section{Free Radical-Scavenging Activity toward DPPH of the LAB Strains}

Antioxidant activity was determined by DPPH free radical-scavenging activity according to Yang et al's method [21]. A volume of $0.4 \mathrm{mM}$ of DPPH solution was prepared in methanol, and $2 \mathrm{ml}$ of bacterial cells or distilled water (control) were mixed with the same volume of this solution. The mixtures were incubated for $30 \mathrm{~min}$ at room temperature in the dark. The absorbance of the supernatants was measured at $517 \mathrm{~nm}$ after centrifugation at $12,000 \times g$ for $10 \mathrm{~min}$, and calculated as follows:

DPPH radical scavenging activity $(\%)=\left(1-\frac{\mathrm{A}_{\text {sample }}}{\mathrm{A}_{\text {control }}}\right) \times 100$

\section{$\beta$-Carotene Bleaching Assay}

A $\beta$-carotene bleaching assay was conducted as described by Kachouri et al. [22] with some modifications. $\beta$ carotene solution was prepared by mixing $3 \mathrm{mg}$ of $\beta$-carotene, linoleic acid $(66 \mu \mathrm{l})$, and Tween $80(300 \mu \mathrm{l})$ with chloroform $(10 \mathrm{ml})$. Chloroform was then removed in a rotary evaporator at $40^{\circ} \mathrm{C}$ under vacuum and the remaining solution was diluted with $100 \mathrm{ml}$ of distilled water. For the assay, $200 \mu \mathrm{l}$ of samples or distilled water (control) was mixed with $4 \mathrm{ml}$ of this solution and incubated in a water bath at $50^{\circ} \mathrm{C}$ for $2 \mathrm{~h}$. Next, absorbance was measured at $470 \mathrm{~nm}$ for 0 and $2 \mathrm{~h}$, and inhibition activity was calculated as follows:

Inhibition activity of $\beta$-carotene oxidation $(\%)=\left(\frac{\mathrm{A}_{\text {sample, } 2 \mathrm{~h}}-\mathrm{A}_{\text {control, } 2 \mathrm{~h}}}{\mathrm{~A}_{\text {control, } 0 \mathrm{~h}}-\mathrm{A}_{\text {control, } 2 \mathrm{~h}}}\right) \times 100$

\section{Cell Viability of RAW 264.7 Cells by LAB Strains}

The effect of LAB strains on the viability of RAW 264.7 cells was evaluated using the MTT assay according to the method described by Han et al. [23] with some modifications. RAW 264.7 cells $\left(1 \times 10^{6} \mathrm{cells} / \mathrm{ml}\right)$ were plated on 96-well cell plates for $24 \mathrm{~h}$. Next, LAB strains were treated with $10^{7} \mathrm{CFU} / \mathrm{ml}$ and incubated for $44 \mathrm{~h}$. After aspiration of supernatant for determination, cells were treated with MTT solution $(2.5 \mathrm{mg} / \mathrm{ml}$ in PBS) and incubated for $4 \mathrm{~h}$. Upon discarding the supernatant, DMSO was added to each well and the generated formazan deposits were dissolved. Absorbance of each well was measured at $570 \mathrm{~nm}$ using a microplate reader. Cell viability was calculated as a percentage of the absorbance.

\section{NO Production in RAW 264.7 Cells}

The production of NO in LPS-induced RAW 264.7 cells was assessed according to the methods of Lee et al. [19]. RAW 264.7 cells $\left(2 \times 10^{5}\right.$ cells/well $)$ were plated in 96-well plates and treated with LAB strains $\left(10^{7} \mathrm{CFU} / \mathrm{ml}\right)$ and LPS $(1 \mu \mathrm{g} / \mathrm{ml})$ for $24 \mathrm{~h}$. The samples were centrifuged at $12,000 \times \mathrm{g}$ for $1 \mathrm{~min}$ after incubation, and $100 \mu \mathrm{l}$ of the supernatants was added to the same amount of Griess reagent. Absorbance of the mixtures was assessed at $540 \mathrm{~nm}$ using a microplate reader. NO production was calculated through comparison with the standard curve constructed with sodium nitrate as a standard.

\section{Anti-Inflammatory Effect of LAB Strains}

The anti-inflammatory effect of LAB strains was measured as described by Lee et al. [19] and Son et al. [24]. RAW 264.7 cells were seeded on a 6 -well plate $\left(1 \times 10^{6}\right.$ cells $\left./ \mathrm{ml}\right)$ and incubated for $24 \mathrm{~h}$ and then added into LPS-

Table 1. Primer sequences related to anti-inflammatory effect used in real-time PCR.

\begin{tabular}{|c|c|c|}
\hline Primer $^{\mathrm{a}}$ & & Primer sequence $\left(5^{\prime}-3^{\prime}\right)$ \\
\hline \multirow[t]{2}{*}{ TNF- $\alpha$} & Sense & 5'-TTG ACC TCA GCG CTG AGT TG-3' \\
\hline & Antisense & 5'-CCT GTA GCC CAC GTC GTA GC-3' \\
\hline \multirow[t]{2}{*}{ iNOS } & Sense & 5'-CCC TTC CGA AGT TTC TGG CAG CAG C-3' \\
\hline & Antisense & 5'-GGC TGT CAG AGC CTC GTG GCT TTG G-3' \\
\hline \multirow[t]{2}{*}{$\mathrm{COX}-2$} & Sense & 5'-CAC TAC ATC CTG ACC CAC TT-3' \\
\hline & Antisense & 5'-ATG CTC CTG CTT GAG TAT GT-3' \\
\hline \multirow[t]{2}{*}{ IL- $1 \beta$} & Sense & 5'-CAG GAT GAG GAC ATG AGC ACC-3' \\
\hline & Antisense & 5'-CTC TGC AGA CTC AAA CTC CAC-3' \\
\hline \multirow[t]{2}{*}{ IL-6 } & Sense & 5'-GTA CTC CAG AAG ACC AGA GG-3' \\
\hline & Antisense & $5^{\prime}$-TGC TGG TGA CAA CCA CGG CC-3' \\
\hline \multirow[t]{2}{*}{$\beta$-Actin } & Sense & $5^{\prime}$-GTG GGC CGC CCT AGG CAC CAG-3' \\
\hline & Antisense & $5^{\prime}$-GGA GGA AGA GGA TGC GGC AGT-3' \\
\hline
\end{tabular}

${ }^{\mathrm{a}} T N F-\alpha$, tumor necrosis factor- $\alpha$; $i N O S$, inducible nitric oxide synthase; COX-2, cyclooxygenase- $2 ; I L-1 \beta$, interleukin- $1 \beta ; I L-6$, interleukin-6. 
Table 2. Tolerance of LAB strains under artificial gastric acid and bile salt conditions.

\begin{tabular}{|c|c|c|c|}
\hline LAB strains & L. rhamnosus GG & L. plantarum KU15149 & L. brevis KU15176 \\
\hline \multicolumn{4}{|c|}{ Tolerance to artificial gastric condition } \\
\hline Initial cell number & $8.31 \pm 0.09^{b}$ & $8.40 \pm 0.10^{\mathrm{a}}$ & $8.28 \pm 0.03^{c}$ \\
\hline $0.3 \%$ pepsin, $\mathrm{pH} 2.5,3 \mathrm{~h}$ & $8.25 \pm 0.10^{b}$ & $8.33 \pm 0.06^{\mathrm{a}}$ & $8.07 \pm 0.13^{c}$ \\
\hline \multicolumn{4}{|c|}{ Tolerance to artificial bile condition } \\
\hline Initial cell number & $8.31 \pm 0.09^{b}$ & $8.40 \pm 0.10^{\mathrm{a}}$ & $8.28 \pm 0.03^{c}$ \\
\hline $0.3 \%$ oxgall, $24 \mathrm{~h}$ & $8.55 \pm 0.02^{\mathrm{a}}$ & $6.87 \pm 0.07^{\mathrm{c}}$ & $7.36 \pm 0.16^{\mathrm{b}}$ \\
\hline
\end{tabular}

All values are expressed as the mean \pm standard deviation. Values with different letters in the same row indicate significant differences for each characteristic $(p<0.05)$.

stimulated $(1 \mu \mathrm{g} / \mathrm{ml})$ and LAB strains $\left(10^{7} \mathrm{CFU} / \mathrm{ml}\right)$. RNA was isolated from RAW 264.7 cells treated with samples using the RNeasy Mini Kit (QIAGEN) and cDNA was synthesized using the Revert Aid First Strand cDNA Synthesis Kit (Thermo Fisher Scientific). The expression levels of iNOS and cytokines related to antiinflammatory effects were measured using synthesized cDNA as a template and a PCR mixture containing SYBR Green PCR Master Mix using RT-PCR (PikoReal 96, Thermo Scientific Pierce). RT-PCR was performed as per the following conditions: $95^{\circ} \mathrm{C}$ for $2 \mathrm{~min}$ followed by 40 cycles of $95^{\circ} \mathrm{C}$ for $5 \mathrm{sec}$ and $60^{\circ} \mathrm{C}$ for $15 \mathrm{sec}$. The results were analyzed after normalization with $\beta$-actin as a reference gene and calculated using the $2^{-\Delta \Delta C t}$ method. The melting curve analysis was performed to assess reaction specificity. The primer sequences are listed in Table 1 .

Statistical Analysis

All experiments were repeated in triplicate and presented as the mean \pm standard deviation. One-way analysis of variance (ANOVA) and Duncan's multiple range test were applied to determine the degree of significant differences. Values were considered significant at $p<0.05$, and all analyses were conducted with the Statistical Package for the Social Sciences (SPSS), version 24 (IBM, USA) program.

\section{Results and Discussions}

\section{Tolerance to Gastric Conditions of LAB Strains}

Tolerance to artificial gastric conditions are characteristic of LAB strains required for probiotic properties in the intestine [25]. The tolerance of L. rhamnosus GG, L. plantarum KU15149 and L. brevis KU15176 to artificial gastric acids and bile salts is indicated in Table 2. All LAB strains exhibited high resistance at $0.2 \log$ CFU to artificial gastric conditions, including $\mathrm{pH} 2.5$ and $0.3 \%$ pepsin. L. rhamnosus GG exhibited the highest resistance to $0.3 \%$ oxgall. The viable cell counts of L. plantarum KU15149 and L. brevis KU15176 were slightly decreased by 1.53 and $0.92 \log$ CFU with bile salts, respectively. L. plantarum Lb41 isolated from kimchi was reduced by $0.06 \log \mathrm{CFU} / \mathrm{ml}$ and $1.36 \log \mathrm{CFU} / \mathrm{ml}$ under strongly acidic and bile salt conditions, respectively [17]. Therefore, L. plantarum KU15149 and L. brevis KU15176 possessed probiotic properties due to resistance to artificial gastric conditions, and these strains could be expected to survive in the gastrointestinal tract.

Enzymatic Activities of LAB Strains

Certain probiotic bacteria are of value as they express enzymes such as $\alpha$-glucosidase, $\beta$-glucosidase, and $\beta$ -

Table 3. Enzymatic activities of LAB strains according to the API ZYM kit.

\begin{tabular}{lccc}
\hline \multicolumn{1}{c}{ Enzyme } & L. rhamnosus GG & L. plantarum KU15149 & L. brevis KU15176 \\
\hline Control & $0^{\mathrm{a}}$ & 0 & 0 \\
Alkaline phosphatase & 0 & 0 & 1 \\
Esterase & 2 & 0 & 2 \\
Esterase lipase & 1 & 1 & 2 \\
Lipase & 0 & 0 & 1 \\
Leucine arylamidase & 3 & 3 & 5 \\
Valine arylamidase & 3 & 2 & 4 \\
Crystine-arylamidase & 0 & 1 & 2 \\
Trypsin & 0 & 0 & 0 \\
$\alpha$-Chymotrypsin & 0 & 0 & 0 \\
Acid phosphatase & 1 & 1 & 2 \\
Naphthol-AS-BI-phosphohydrolase & 2 & 1 & 1 \\
$\alpha$-Galactosidase & 0 & 0 & 5 \\
$\beta$-Galactosidase & 1 & 5 & 0 \\
$\beta$-Glucuronidase & 0 & 0 & 1 \\
$\alpha-G l u c o s i d a s e$ & 0 & 0 & 4 \\
$\beta$-Glucosidase & 1 & 4 & 5 \\
N-Acetyl- $\beta$-glucosaminidase & 0 & 3 & 0 \\
$\alpha-M a n n o s i d a s e$ & 0 & 0 & 0 \\
$\alpha$-Fucosidase & 0 & 0 & \\
\hline
\end{tabular}

$0^{\mathrm{a}}$, $0 \mathrm{nmol} ; 1,5 \mathrm{nmol} ; 2,10 \mathrm{nmol} ; 3,20 \mathrm{nmol} ; 4,30 \mathrm{nmol} ; 5, \geq 40 \mathrm{nmol}$. 
Table 4. Antibiotic sensitivities of LAB strains.

\begin{tabular}{lccc}
\hline \multicolumn{1}{c}{ Antibiotics } & L. rhamnosus GG & L. plantarum KU15149 & L. brevis KU15176 \\
\hline Ampicillin (10 mg) & $\mathrm{S}$ & $\mathrm{S}$ & $\mathrm{S}$ \\
Gentamycin (10 mg) & $\mathrm{R}$ & $\mathrm{R}$ & $\mathrm{R}$ \\
Kanamycin (30 mg) & $\mathrm{R}$ & $\mathrm{R}$ & $\mathrm{R}$ \\
Streptomycin (10 mg) & $\mathrm{R}$ & $\mathrm{R}$ & $\mathrm{R}$ \\
Tetracycline (30 mg) & $\mathrm{S}$ & $\mathrm{R}$ & $\mathrm{S}$ \\
Ciprofloxacin (30 mg) & $\mathrm{R}$ & $\mathrm{R}$ & $\mathrm{R}$ \\
Chloramphenicol (30 mg) & $\mathrm{S}$ & $\mathrm{I}$ & $\mathrm{S}$ \\
Doxycycline (30 mg) & $\mathrm{S}$ & $\mathrm{S}$ & $\mathrm{S}$ \\
\hline
\end{tabular}

Resistance was evaluated according to the CLSI breakpoints (CLSI, 2012).

S, Susceptible; I, intermediate; R, resistant.

galactosidase. $\beta$-galactosidase hydrolyzes lactose into glucose and galactose in milk and alleviates the lactose intolerance problem experienced by some adults $[26,27]$. In addition, probiotic bacteria should not produce enzymes such as $\beta$-glucuronidase, which has been associated with the induction of carcinogenesis, mutagens, and toxins [28]. The enzymatic activities of the LAB strains tested are shown in Table 3. Although $L$. rhamnosus GG, $L$. plantarum KU15149, and L. brevis KU15176 produced $\beta$-galactosidase, none of the LAB strains produced $\beta$ glucuronidase. A previous study indicated that probiotic L. plantarum FI10604 and L. brevis FI10700 also do not produce $\beta$-glucuronidase [11]. Lactococcus lactis KC24 produces various enzymes, such as acid phosphatase, $\beta$ galactosidase, and naphthol-AS-BI-phosphohydrolase, but does not produce $\beta$-glucuronidase [19].

\section{Antibiotic Sensitivity of LAB Strains}

The sensitivity of probiotic bacteria to antibiotics is a fundamental precondition because antibiotic-resistant strains may not be easily eliminated if required, and their antibiotic resistance may be transmitted to pathogenic or potentially pathogenic bacteria [29]. The antibiotic sensitivity of LAB strains is presented in Table 4. L. brevis KU15176 had the same sensitivity as L. rhamnosus GG, and in the case of L. plantarum KU15149, it had a similar sensitivity, except to tetracycline $(30 \mathrm{mg})$ and chloramphenicol $(30 \mathrm{mg})$. L. plantarum $\mathrm{Ln} 4$ has been shown to be sensitive to commercial antibiotics, such as ampicillin, chloramphenicol, doxycycline, and tetracycline [11]. Therefore, these results confirm that LAB strains are safe in accordance with the CLSI guidelines.

\section{Adhesion of LAB Strains to HT-29 Cells}

The adhesion of LAB strains to intestinal cells is the most important factor in their effective use [30]. LAB strain adhesion to HT-29 cells is shown in Fig. 1. L. plantarum KU15149 and L. brevis KU15176 demonstrated a similar ability to adhere to HT-29 cells. L. rhamnosus GG had the greatest adhesion ability (6.37\%), followed by L. plantarum KU15149 (2.39\%) and L. brevis KU15176 (2.61\%). Song et al. [31] previously showed that L. brevis KCCM 12203P (6.84\%) has a slightly higher adhesion ability to intestinal epithelial cells compared to that of L. rhamnosus GG (6.21\%). Zhang et al. [32] showed that $L$. plantarum $\mathrm{C} 32, \mathrm{C} 42$, and $\mathrm{C} 62(<2 \%)$ have diminished adhesion ability to intestinal epithelial cells compared to that of $L$. rhamnosus GG (4.30\%). Therefore, although the adhesion ability of L. plantarum KU15149 (2.39\%) and L. brevis KU15176 (2.61\%) to intestinal cells was lower than that of the commercial strain, L. rhamnosus GG (6.21\%), this was still considered sufficient for use as a functional probiotic.

\section{Antioxidant Effect of LAB Strains}

The critical role of $L A B$ strains in antioxidant activity is protection from free radicals [33]. The antioxidant activity of LAB strains was assessed by DPPH free radical scavenging (Fig. 2A) and $\beta$-carotene bleaching assays (Fig. 2B).

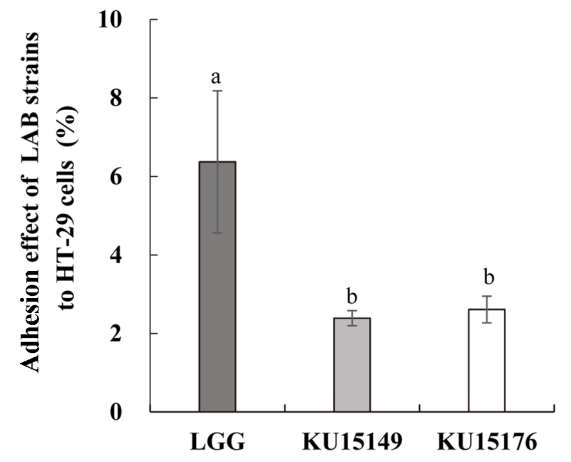

Fig. 1. Adhesion of LAB strains to HT-29 cells. LGG, L. rhamnosus GG; KU15149, L. plantarum KU15149; KU15176, L. brevis KU15176. Error bars indicate standard deviation of three independent experiments. Letters indicate a significant difference between prospective and commercial probiotic strain. All values are expressed as the mean \pm standard deviation. Values with different letters indicate significant differences for each characteristic $(p<0.05)$. 

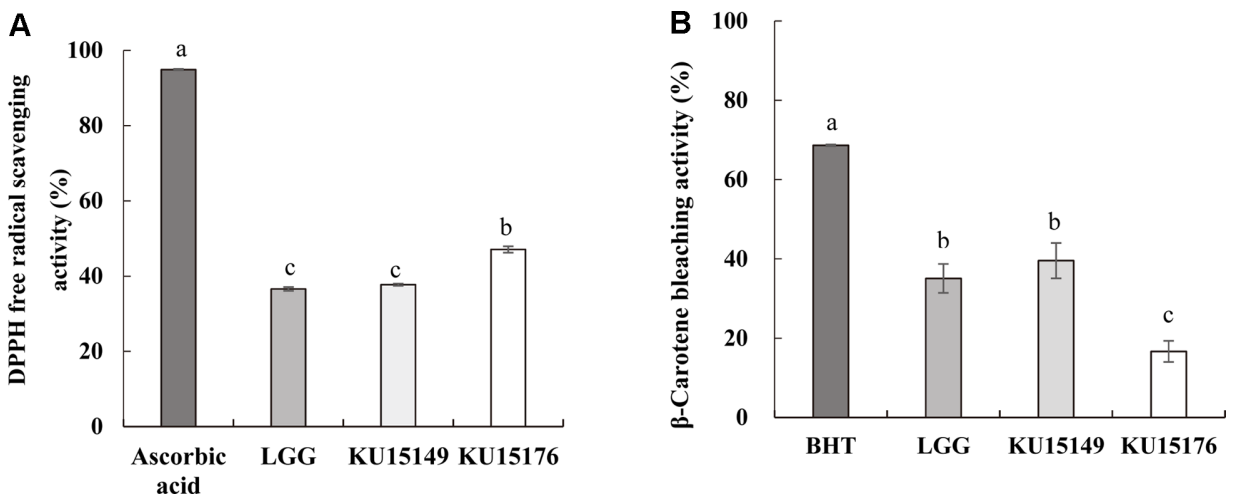

Fig. 2. Antioxidant activity of LAB strains assessed by (A) DPPH free-radical scavenging and (B) $\beta$-carotene bleaching assays. BHT, Butylated hydroxytoluene; LGG, L. rhamnosus GG; KU15149, L. plantarum KU15149; KU15176, L. brevis KU15176. Letters a-c denote a significant difference between prospective and commercial probiotic strains. Each value is expressed as the mean \pm standard deviation. The different letters on the error bars represent statistically significant differences between values $(p<0.05)$.

L. brevis KU15176 (47.09\%) showed significantly higher DPPH free-radical scavenging activity than that of L. rhamnosus GG (36.60\%), while the activity of L.plantarum KU15149 (37.73\%) was similar to that of L. rhamnosus GG. In a prior study, L. brevis KU15153 (44.14\%) has been shown to exhibit higher DPPH freeradical scavenging activity than L. rhamnosus GG (19.21\%) [34]. The $\beta$-carotene bleaching inhibition activity of LAB strains is depicted in Fig. 2B. The $\beta$-carotene bleaching inhibition activity of L. plantarum KU15149 (39.57\%) was higher than that of L. brevis KU15176 (16.65\%) but not significantly different from that of L. rhamnosus GG (35.08\%). Another study found that $L$. paraplantarum SC61 showed $35.64 \%$ inhibition of $\beta$-carotene bleaching activity [24]

Anti-Inflammatory Activity of LAB Strains

To confirm cytotoxicity in RAW 264.7 cells, the viability of LAB was determined using the MTT assay (data not shown). The LAB strains were shown to have higher viability at $10^{7} \mathrm{CFU} / \mathrm{ml}$ than at $10^{8} \mathrm{CFU} / \mathrm{ml}$. Therefore, $\mathrm{LAB}$ strains were tested at a concentration of $10^{7} \mathrm{CFU} / \mathrm{ml}$ for induction of $\mathrm{NO}$ synthesis in macrophages.

The NO-producing activity of $L$. plantarum KU15149 $(2.25 \mu \mathrm{M})$ was the lowest in comparison to that of
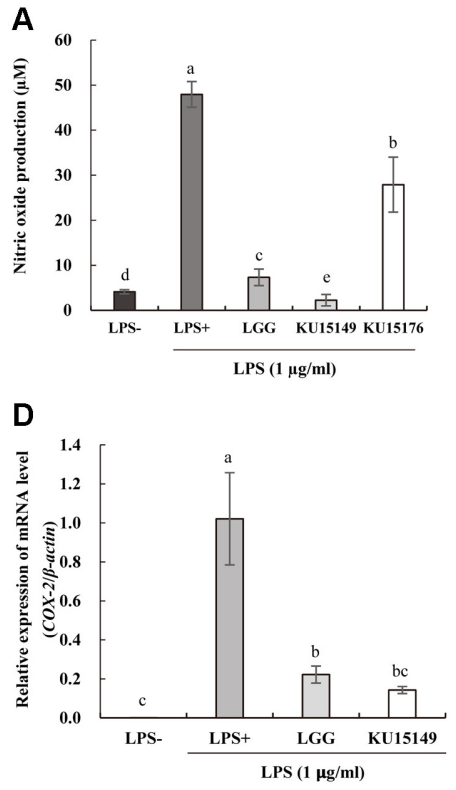

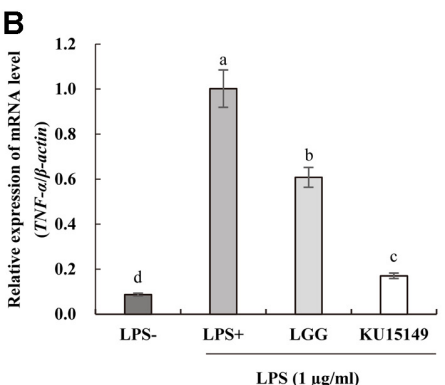

E

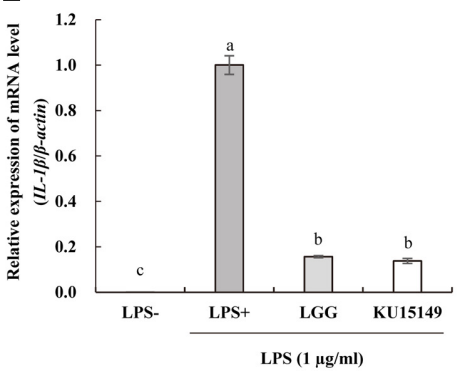

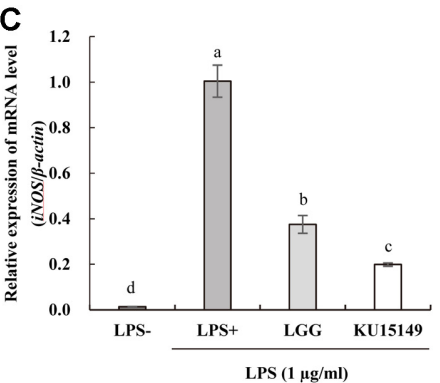

$\mathbf{F}$

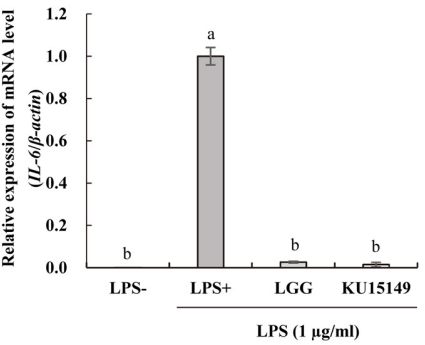

Fig. 3. Production of (A) NO on LAB strains in lipopolysaccharide (LPS)-stimulated RAW264.7 cells and the relative expression of mRNA level of (B) TNF- $\alpha$, (C) iNOS, (D) COX-2, (E) $I L-1 \beta$, and (F) $I L-6$. LPS-, without LPS treatment; LPS+, treated with LPS (1 $\mu \mathrm{g} / \mathrm{ml}) ;$ LGG, L. rhamnosus GG with LPS; KU15149, L. plantarum KU15149 with LPS. All values are expressed as the mean \pm standard deviation and standardized against the $\beta$-actin housekeeping gene. Values with different letters indicate significant differences for each characteristic $(p<0.05)$. 
L. rhamnosus GG $(7.32 \mu \mathrm{M})$ and L. brevis $\mathrm{KU} 15176(25.57 \mu \mathrm{M})$ in stimulating LPS conditions (Fig. 3A). Lactococcus lactis NK34 has been reported to possess low levels of NO production [23] and L. plantarum 4B15 and $4 \mathrm{M} 13$ have been found to exert the greatest inhibitory effect on NO production [35].

LAB strains were analyzed for mRNA expression levels of TNF- $\alpha$, iNOS, COX-2, IL-1 $\beta$, and $I L-6$ from RAW 264.7 cells through RT-qPCR (Figs. 3B-3F). Both L. plantarum KU15149 and L. rhamnosus GG demonstrated significant decrease in all five mRNAs assessed when compared to the LPS+ control. L. plantarum KU15149 was associated with a significant decrease in relative expression of TNF- $\alpha$ and $i N O S$ in comparison to L. rhamnosus GG, suggesting that $L$. plantarum KU15149 would be more effective in dampening an LPS-induced immune response; levels of $C O X-2, I L-1 \beta$, and $I L-6$ mRNA expression showed no significant difference between the two strains. Weissella cibaria JW15 has been shown to significantly inhibit the expression of pro-inflammatory cytokines compared to L. rhamnosus GG [36].

In conclusion, L. plantarum KU15149 isolated from homemade diced-radish kimchi was found to have probiotic properties including gastric acid and bile salt tolerance, enzyme activity, adhesion to intestinal cells, and antibiotic sensitivity. L. plantarum KU15149 had a high abundance of antioxidants, as measured by DPPH freeradical scavenging and $\beta$-carotene bleaching inhibition. In addition, $L$. plantarum KU15149 induced lower levels of NO and less expression of pro-inflammatory cytokine genes TNF- $\alpha$ and $i N O S$ than did L. rhamnosus GG under LPS-induced conditions in macrophages. Therefore, L. plantarum KU15149 could be potentially used as a probiotic and anti-inflammatory ingredient.

\section{Conflict of Interest}

The authors have no financial conflicts of interest to declare.

\section{References}

1. Rahman T, Hosen I, Islam MMT, Shekhar HU. 2012. Oxidative stress and human health. Adv. Biosci. Biotechnol. 3: 997-1019.

2. Carocho M, Ferreira IC. 2013. A review on antioxidants, prooxidants and related controversy: natural and synthetic compounds, screening and analysis methodologies and future perspectives. Food Chem. Toxicol. 51: 15-25.

3. Dröge W. 2002. Free radicals in the physiological control of cell function. Physiol. Rev. 82: 47-95.

4. Lawrence T, Willoughby DA, Gilroy DW. 2002. Anti-inflammatory lipid mediators and insights into the resolution of inflammation. Nat. Rev. Immunol. 2: 787-795.

5. Duque GA, Descoteaux A. 2014. Macrophage Cytokines: Involvement in immunity and infectious diseases. Front Immunol. 5: 491.

6. FAO/WHO. 2002. Working group report on drafting guidelines for the evaluation of probiotics in food. World Health Organization and Food and Agriculture Organization of the United Nations. Ontario: London.

7. Khan I, Kang SC. 2016. Probiotic potential of nutritionally improved Lactobacillus plantarum DGK-17 isolated from kimchi-A traditional Korean fermented food. Food Control 60: 88-94.

8. Tokatlı M, Gülgör G, Elmacı SB, EGleyen NA, Özçelik F. 2015. In vitro properties of potential probiotic indigenous lactic acid bacteria originating from traditional pickles. Biomed. Res. Int. 2015: 315819.

9. Shao Y, Zhang W, Guo H, Pan L, Zhang H, Sun T. 2015. Comparative studies on antibiotic resistance in Lactobacillus casei and Lactobacillus plantarum. Food Control 50: 250-258.

10. Lee NK, Kim SY, Han KJ, Eom SJ, Paik HD. 2014. Probiotic potential of Lactobacillus strains with anti-allergic effects from kimchi for yogurt starters. LWT - Food Sci. Technol. 58: 130-134.

11. Son SH, Jeon HL, Jeon EB, Lee NK, Park YS, Paik, HD. 2017. Potential probiotic Lactobacillus plantarum Ln4 from kimchi: Evaluation of $\beta$-galactosidase and antioxidant activities. LWT - Food Sci. Technol. 85: 181-186.

12. Cuello-Garcia CA, Brożek JL, Fiocchi A, Pawankar R, Yepes-Nuñez JJ, Terracciano L, et al. 2015. Probiotics for the prevention of allergy: A systematic review and meta-analysis of randomized controlled trials. J. Allergy Clin. Immunol. 136: 952-961.

13. Lee DY, Kim SJ, Cho JH and Kim JH. 2008. Microbial population dynamics and temperature changes during fermentation of kimjang kimchi. J. Microbiol. 46: 590-593.

14. Lee. KW, Park JY, Sa HD, Jeong JH, Jin DE, Heo HJ, Kim JH. 2014. Probiotic properties of Pediococcus strains isolated from jeotgals, salted and fermented Korean sea-food. Anaerobe 28: 199-206.

15. Park KY, Jeong JK, Lee YE, Daily JW III. 2014. Health benefits of kimchi (Korean fermented vegetables) as a probiotic food. J. Med. Food 17: 6-20.

16. Lee ME, Jang JY, Lee JH, Park HW, Choi HJ, Kim TW. 2015. Starter cultures for kimchi fermentation. J. Microbiol. Biotechnol. 25: 559568 .

17. Jeon EB, Son SH, Jeewanthi RKC, Lee NK, Paik HD. 2016. Characterization of Lactobacillus plantarum Lb41, an isolate from kimchi and its application as a probiotic in cottage cheese. Food Sci. Biotechnol. 25: 1129-1133.

18. Jiang M, Zhang F, Wan C, Xiong Y, Shah NP, Wei H, et al. 2016. Evaluation of probiotic properties of Lactobacillus plantarum WLPL04 isolated from human breast milk. J. Dairy Sci. 99: 1736-1746.

19. Lee NK, Han KJ, Son SH, Eom SJ, Lee SK, Paik HD. 2015. Multifunctional effect of probiotic Lactococcus lactis KC24 isolated from kimchi. LWT - Food Sci. Technol. 64: 1036-1041.

20. CLSI. 2012. Performance standards for antimicrobial susceptibility testing; twenty-second informational supplement. Clin. Lab. Standards Institute 32: 44-49.

21. Yang SJ, Lee JE, Lim SM, Kim YJ, LEE NK, Paik HD. 2019. Antioxidant and immune-enhancing effects of probiotic Lactobacillus plantarum 200655 isolated from kimchi. Food Sci. Biotechnol. 28: 491-499.

22. Kachouri F, Ksontini H, Kraiem M, Setti K, Mechmeche M, Hamdi M. 2015. Involvement of antioxidant activity of Lactobacillus plantarum on functional properties of olive phenolic compounds. J. Food Sci. Technol. 52: 7924-7933.

23. Han KJ, Lee NK, Park H, Paik HD. 2015. Anticancer and anti-Inflammatory activity of probiotic Lactococcus lactis NK34. J. Microbiol. Biotechnol. 25: 1697-1701.

24. Son SH, Yang SJ, Jeon HL, Yu HS, Lee NK, Park YS, Paik HD. 2018. Antioxidant and immunostimulatory effect of potential probiotic Lactobacillus paraplantarum SC61 isolated from Korean traditional fermented food, jangajji. Microb. Pathog. 125: 486-492.

25. Anukam KC, Koyama TE. 2007. Bile and acid tolerance of Lactobacillus plantarum KCA-1: a potential probiotical agent. Int. J. Dairy Sci. 2: 275-280.

26. De Vrese M, Stegelmann A, Richter B, Fenselau S, Laue C, Schrezenmeir J. 2001. Probiotics-compensation for lactase insufficiency. Am. J. Clin. Nutr. 73: 421-429. 
27. Vasiljevic T, Jelen P. 2001. Production of $\beta$-galactosidase for lactose hydrolysis in milk and dairy products using thermophilic lactic acid bacteria. Innov. Food Sci. Emerg. Technol. 2: 75-85.

28. Dabek M, McCrae SI, Stevens VJ, Duncan SH, Louis P. 2008. Distribution of $\beta$-glucosidase and $\beta$-glucuronidase activity and of $\beta$ glucuronidase gene gus in human colonic bacteria. FEMS Microbiol. Ecol. 66: 487-495.

29. Coppola R, Succi M, Tremonte P, Reale A, Salzano G, Sorrentino E. 2005. Antibiotic susceptibility of Lactobacillus rhamnosus strains isolated from Parmigiano Reggiano cheese. Dairy Sci. Tech. 85: 193-204.

30. Monteagudo-Mera A, Robert A. Rastall RA, Gibson GR, Charalampopoulos D, Chatzifragkou A. 2019. Adhesion mechanisms mediated by probiotics and prebiotics and their potential impact on human health. Appl. Microbiol. Biotechnol. 103: 6463-6472.

31. Song MW, Jang HJ, Kim KT, Paik HD. 2019. Probiotic and antioxidant properties of novel Lactobacillus brevis KCCM 12203P isolated from kimchi and evaluation of immune-stimulating activities of its heat-killed cells in RAW 264.7 cells. J. Microbiol. Biotechnol. 29: 1894-1903.

32. Zhang J, Zhang X, Zhang L, Zhao Y, Niu C, Yang Z, et al. 2014. Potential probiotic characterization of Lactobacillus plantarum strains isolated from inner mongolia "Hurood" cheese. J. Microbiol. Biotechnol. 24: 225-235.

33. Ren D, Li C, Qin Y, Yin R, Du S, Ye F, et al. 2014. In vitro evaluation of the probiotic and functional potential of Lactobacillus strains isolated from fermented food and human intestine. Anaerobe 30: 1-10.

34. Jang HJ, Lee NK, Paik HD. 2019. Probiotic characterization of Lactobacillus brevis KU15153 showing antimicrobial and antioxidant effect isolated from kimchi. Food Sci. Biotechnol. 28: 1521-1528.

35. Oh NS, Joung JY, Lee JY, Kim YH. 2018. Probiotic and anti-inflammatory potential of Lactobacillus rhamnosus 4B15 and Lactobacillus gasseri 4M13 isolated from infant feces. PLoS One 13: e0192021.

36. Yu HS, Lee NK, Choi AJ, Choe JS, Bae CH, Paik HD. 2019. Anti-Inflammatory potential of probiotic strain Weissella cibaria JW15 isolated from kimchi through regulation of NF- $\kappa$ B and MAPKs pathways in LPS-induced RAW 264.7 cells. J. Microbiol. Biotechnol. 29: $1022-1032$ 